\title{
Comparative study of five pleurotus species cultivated in warm temperature on non-sterilized rice straw
}

\author{
Nirmalendu Das*, Sweta Mishra, Laltu Biswas, Narayan Chandra Karmakar \\ Post Graduate, Department of Botany, Barasat Govt. College, Kolkata, India, 700124
}

\section{A B S T R A C T}

\begin{abstract}
Five different Pleurotus species are cultivated on non-sterilized rice straw at $30 \pm 2{ }^{\circ} \mathrm{C}$. Smaller length of the substrate $(1 \mathrm{~cm})$ showed better biological efficiency $(B E)$ than the longer substrate $(5 \mathrm{~cm}) .20 \%$ spawn showed better efficiency than $10 \%$ spawn though spawn percentage has no effect on time of fruiting initiation. Length of the rice substrate much influenced the BE of $P$. pulmonarius whereas spawn percentage has more effect in $P$. florida than other species. The BE of $P$. pulmonarius and $P$. florida are comparable in first flush of production where $20 \%$ spawn and low substrate length are used. Early fruiting was observed in $P$. ostreatus followed by $P$. pulmonarius whereas $P$. floridanus showed more time requirement for initiation of fruiting. Morphometric data of fruiting body and basidium were generated. The protein, carbohydrate and polyphenol conc. were maximum in $P$. ostreatus and lowest in $P$. florida. Amount of moisture, crude fibre, ash, sodium, potassium contents are also determined in all the five species of oyster mushroom.
\end{abstract}

Keywords: Biological efficiency; Fruiting body; Morphometrics; Nutriceuticals; Oyster mushroom

\section{INTRODUCTION}

After Yeast fermentation, mushroom production has been considered as second most amongst the esteemed commercial microbial technologies (Sanchez, 2010). Due to the intrinsic tendency to grow upon a variety of substrates, mushrooms are considered to recycle organic wastes which unless are problematic for disposal (Croan, 2004). Cultivation of mushroom does not require fertile land as they can grow in the sheltered rooms degrading altogether various agro-residues (Gregori et al., 2007). Utilization of mushrooms as an alternative source of protein has been emphasized to be of great enthusiasm to the researchers for last few decades (Chang, 1999). Kurtzman (1976) considered mushroom protein as intermediate between that of animals and vegetables whereas Purkayastha and Nayak (1981) considered them as of superior qualities because of the presence of all the essential amino acids. Weinheim (2006) suggested that mushroom contains low calories and provide essential minerals thus regarded as a valuable health food. A number of edible mushroom species like Agaricus, Auricularia, Calocybe, Flammulina, Lentinus Pleurotus, Volvariella, etc. are commercially cultivated in different parts of the globe.
A number of mushrooms are considered not only as nutritionally rich food but also valuable from the viewpoint of medicinal purposes (Gregori et al, 2007; Novaes et al., 2007). Button mushroom (Agaricus spp) and shitake (Lentinus spp) are widely accepted for commercial production. In recent days Oyster mushroom (Pleurotus spp.) are widely cultivated throughout the world due to their low cost production technology and higher biological efficiency (Mane et al. 2007). Oyster mushroom cultivation has now stepped up in second position after the button mushroom in terms of production turnover around the planet (Chang, 1999; Sanchez, 2010). Though oyster mushroom are initially cultivated in temperate countries like China, South Korea etc. but now-a-days its cultivation is flourishing also in tropical countries like India (Biswas, Datta \& Ngachan, 2012).

In the present study five Pleurotus spp. are cultivated on non-sterilized rice straw in warm temperature $\left(30^{\circ} \mathrm{C}\right)$ and optimal condition in respect to substrate length and spawn percentage are determined. Morphometric data, physiochemical analysis and centesimal composition of different mushrooms obtained from optimized condition are evaluated.

\footnotetext{
*Corresponding author:

Nirmalendu Das, Post Graduate, Department of Botany, Barasat Govt. College, Kolkata, India, 700124. E-mail: nirmalendus@yahoo.co.uk 


\section{MATERIALS AND METHODS}

\section{Mushroom species}

Five Pleurotus spp. were used in the present study. Pleurotus flabellatus (MTCC 1799), Pleurotus ostreatus (MTCC 1802), Pleurotus pulmonarius (MTCC 1805) and Pleurotus floridanus (MTCC 6315) were obtained from Microbial Type Culture Collection and Gene Bank, Institute of Microbial Technology, Chandigarh, India whereas Pleurotus florida (ITCC 3308)) was obtained from Society for Rural Industrialization, Ranchi, India. All the species were maintained in PDA medium (Das and Mukherjee, 2007).

\section{Spawn preparation}

About 1000 gm of wheat grains has been taken for spawn production. The grains were boiled for half an hour then washed in flowing water. Excess water present was drained off and the grains were spread on the surface of clean blotting paper and air dried. $10 \mathrm{gm}$ of calcium sulphate and $5 \mathrm{gm}$ of calcium carbonate were mixed with the grains. Then about $100 \mathrm{gm}$ of grain was placed in conical flask $(250 \mathrm{ml})$ and sterilized in autoclave at $121^{\circ} \mathrm{C}$ for $15 \mathrm{~min}$ and inoculated with the respective mushroom strains and kept at $30^{\circ} \mathrm{C}$ for 15 days (Das et al., 2010).

\section{Substrate preparation}

Dried rice straw has been collected from a local farm at Barasat, West Bengal, India. The chopped rice straws $(1 \mathrm{~cm} / 5 \mathrm{~cm})$ are weighed and soaked in water for overnight. Excess water present in the substrate was drained off and the substrate is air dried for $15 \mathrm{~min}$. There is no heat treatment of the substrate. About $750 \mathrm{gm}$ wet substrate was mixed with either $10 \%$ or $20 \%$ spawn (wet wt./wet wt.). These spawned substrates were then put into $30 \mathrm{~cm} \times 42 \mathrm{~cm}$ polythene bags. The bags were closed tightly with pin holes on the surfaces and kept in $30 \pm 2{ }^{\circ} \mathrm{C}$ (Das et al., 2010).

\section{Biological efficiency (BE)}

BE was calculated according to Das et al. (2010).

$\mathrm{BE}(\%)=($ fresh weight of mushroom $\times 100) /$ dry weight of substrate

\section{Microscopical studies}

Microscopical studies and measurement were done using Carl Zeiss Microscope, Germany and measurement were done using Axio Vs 401E V4.3.0.101 (2004) software.

\section{Preparation of fruiting body extract for determination of protein and carbohydrate}

Fresh fruiting bodies $(30 \mathrm{~g})$ were disrupted by being crushed with acid washed sea sand in mortar and pestle. Then tissues were extracted with $100 \mathrm{ml}$ of $20 \mathrm{mM}$ imidazole buffer containing $1 \mathrm{mM}$ EDTA, 2 mM PMSF (pH 7.8). Unbroken cells and cell debris were removed after centrifugation at $10000 \mathrm{rpm}$ for $30 \mathrm{~min}$ and the supernatant was used for determination of protein and carbohydrate (Das and Mukherjee, 2007).

\section{Protein determination}

Protein concentration was determined by the method of Lowry et al. (1951) with slight modification. At first Lowry A ( $2 \%$ sodium carbonate mixed with $0.1 \mathrm{~N} \mathrm{NaOH}$ solution) and Lowry B (1.56\% copper sulphate solution mixed with $2.37 \%$ sodium potassium tartarate) reagents were prepared. Lowry $\mathrm{C}$ reagent was made by mixing $2 \mathrm{ml}$ of (Lowry B) with $100 \mathrm{ml}$ of (Lowry A). $20 \mu \mathrm{l}$ mushroom extract was mixed with $980 \mu \mathrm{l}$ of distilled water and incubated for 15 min after addition of $2 \mathrm{ml}$ Lowry $\mathrm{C}$ reagent. After incubation $1 \mathrm{ml} 1 \mathrm{~N}$ Folin - Ciocalteau reagent solution (Diluted 2N commercial reagent with an equal volume of water on the day of use) was mixed and incubated for $30 \mathrm{~min}$ in dark condition. The OD values were taken at $660 \mathrm{~nm}$ and the protein values of mushroom samples were determined by comparing the standard curve of BSA.

\section{Carbohydrate determination}

Total carbohydrate was determined using anthrone reagent according to Pons et al. (1981) with some modifications. $100 \mu \mathrm{l}$ of the sample was taken in a test tube and $5 \mathrm{ml}$ of $2.5 \mathrm{~N} \mathrm{HCl}$ was added with it. Hydrolyzed the mixture in a boiling water bath for three hours and neutralized it with solid sodium carbonate until the effervescence ceased. Made up the volume to $100 \mathrm{ml}$ and centrifuged. Supernatant was collected. One $\mathrm{ml}$ of sample was mixed with $4 \mathrm{ml}$ of anthrone reagent. The mixture was boiled for eight minutes in a boiling water bath. The OD values were taken at $630 \mathrm{~nm}$ after rapid cooling. The carbohydrate content of mushroom samples were determined by comparing the standard curve of glucose.

\section{Polyphenol determination}

Oven dried mushroom powder (500 mg) was mixed with $2 \mathrm{ml}$ of $80 \%$ methanol. It was centrifuged at 10,000 rpm for $30 \mathrm{~min}$. This process is repeated thrice by same way mixing with $80 \%$ methanol extract with pellet. Finally supernatant is collected and volume made up to $5 \mathrm{ml}$ by adding $80 \%$ methanol. $2 \mathrm{ml}$ supernatant was taken in a petriplate, evaporated to dryness then dissolved the residue in $2 \mathrm{ml}$ distilled water. $1 \mathrm{ml}$ sample has been taken and mixed with $2 \mathrm{ml} \mathrm{Na}_{2} \mathrm{CO}_{3}(2 \%)$, after 2 min incubation $1 \mathrm{ml}$ Folin - Ciocalteau reagent is added. After 30 min incubation at room temperature $\mathrm{OD}_{720}$ has been taken and compared with gallic acid standard. 


\section{Determination of moisture content and dry matter of mushroom}

Fresh mushroom fruiting bodies were weighed and kept in oven at $60{ }^{\circ} \mathrm{C}$ for overnight until the constant weight was gained. The moisture content and dry matter of Pleurotus spp. were calculated according the following formulas given by Khan et al. (2013).

Moisture content $(\%)=100 \mathrm{X}\left(\mathrm{W}_{1}-\mathrm{W}_{2}\right) / \mathrm{W}_{1}$

Dry matter $(\%)=100 \mathrm{X} \mathrm{W}_{2} / \mathrm{W}_{1}$

Where $W_{1}=$ weight of fresh sample

$\mathrm{W}_{2}=$ weight of dry sample

\section{Determination of ash content}

One gram of oven dried sample was taken in cleaned and previously weighed china crucible. After ignition on a flame, crucible was placed in a muffle furnace at $(550 \pm 50){ }^{\circ} \mathrm{C}$ for three hours. After that crucible was cooled in desiccator and then weighed. Ash contents were calculated according to the formula of Khan et al. (2013).

Ash $(\%)=100 \mathrm{X}\left(\mathrm{W}_{2}-\mathrm{W}_{1}\right) /$ weight of sample

Where $\mathrm{W}_{1}=$ weight of crucible

$\mathrm{W}_{2}=$ weight of crucible \pm material

\section{Determination of crude fiber content}

The crude fibre content was determined according to Khan et al. (2013). Sample (10 g) was heated at simmering temperature $\left(80^{\circ} \mathrm{C}\right.$ ) with $200 \mathrm{ml} \mathrm{H}_{2} \mathrm{SO}_{4}$ and kept about half an hour. Through frequent addition of hot water the medium volume was kept constant. After addition of $500 \mathrm{ml}$ cold water, the boiling was stopped. The content was filtered immediately under vacuumed condition. The residues were washed for several times with hot water and digested. The digested sample was then filtered until become neutral after addition of acetone. The residues were properly washed and transferred to crucible. The sample was then dried in constant weight. Crucible was placed in the muffle furnace at $65^{\circ} \mathrm{C}$ for ignition. The ash and crude fibre was calculated according to the following formula

Crude fibre $(\%)=a-(b / w) \times 100$

Where $a=$ Dry weight after digestion.

$\mathrm{b}=$ weight of ash

$\mathrm{w}=$ weight of sample
Determination of sodium and potassium in mushroom strains

Dried mushroom powder $(0.5 \mathrm{~g})$ was taken in $50 \mathrm{ml}$ volumetric flask and $5 \mathrm{ml}$ ternary acid (made by nitric acid, $\mathrm{H}_{2} \mathrm{SO}_{4}$ and perchloric acid in 9:4:1 ratio) was added with it. Then the mixture was heated on the hot plate until it turned colorless and transparent. After that volume was made up to $50 \mathrm{ml}$ by distilled water in volumetric flask. Then calculate $\mathrm{Na} / \mathrm{K}$ in flame photometer against standard solution.

\section{Statistical analysis}

All experiments were conducted in nine replicates $(3$ sets $x 3$ batches) and the parameters were given as mean \pm standard deviation. Both mean and standard deviation were performed where appropriate, using the statistical package within Microsoft ${ }^{\circledR}$ Excel Version 2010. Graphs were drawn using GraphPad Prism V.5.

\section{RESULTS}

\section{Effect of substrate length}

All the tested five Pleurotus species are cultivated in nonsterilized rice straw at $30 \pm 2^{\circ} \mathrm{C}$. In present experimental condition two types of rice straw are used. One of very small length about $1.0 \mathrm{~cm}$ and other of $5.0 \mathrm{~cm}$ length. The results show that the biological efficiencies are much better in tiny straw substrates $(1.0 \mathrm{~cm})$ than the straw with higher length $(5.0 \mathrm{~cm})$ (Fig. 1). 1805 shows highest BE in first flush using $1.0 \mathrm{~cm}$ rice straw as substrate wheres 1802 shows least $\mathrm{BE}$ in $2^{\text {nd }}$ flush using $5.0 \mathrm{~cm}$ rice straw substrate. The time requirement for initiation of fruiting bodies are same or slightly less in smaller length of substrates (Table-1). Hence subsequently in all other experiments smaller length of rice straw substrate is used. 6315 requires about $24 \pm 2$ days for

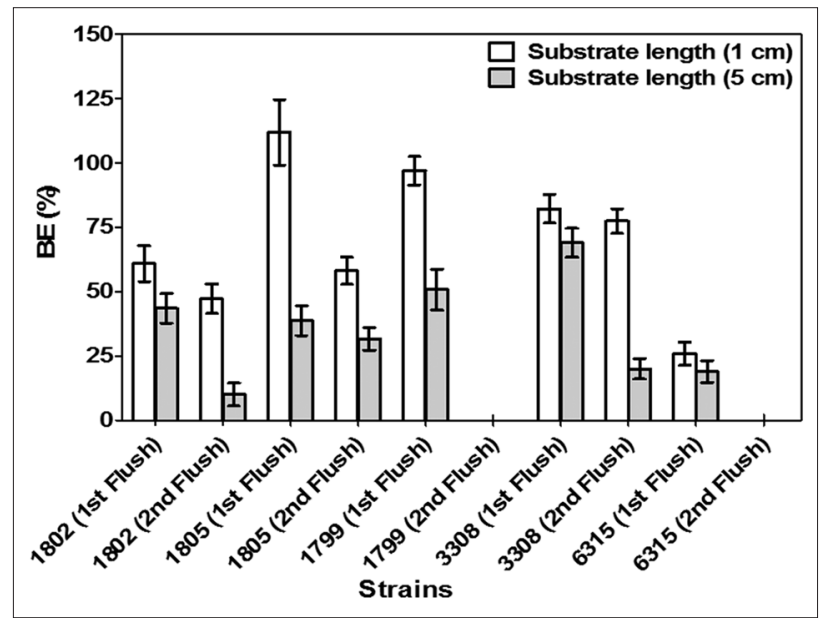

Fig 1. Effect of substrate length on BE of two flushes of different oyster mushroom strains at $30 \pm 2{ }^{\circ} \mathrm{C}$ (Bars $=$ Standard deviations). Non-sterilized rice straw of different length $(1 \mathrm{~cm} \mathrm{\&} 5 \mathrm{~cm})$ are used as substrates. $10 \%$ (wet wt./wet wt.) spawn are used. 


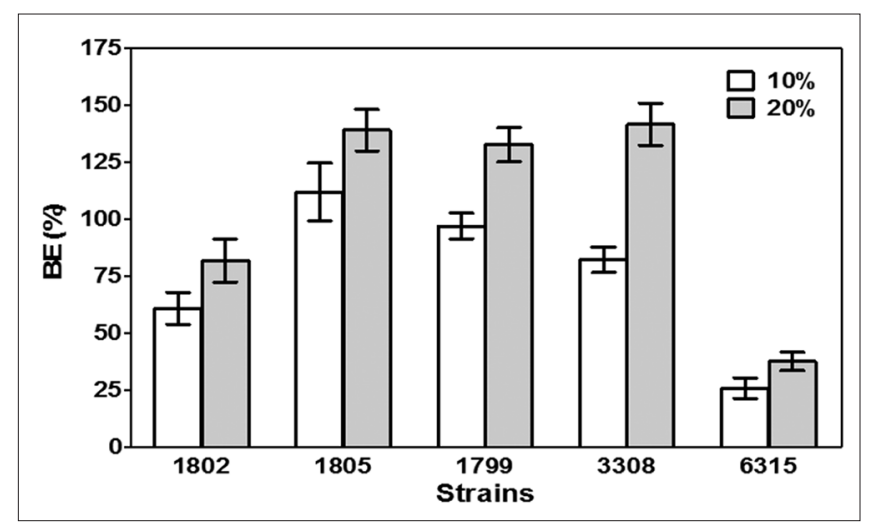

Fig 2. Effect of spawn percentage on BE of $1^{\text {st }}$ flush of different strains of Pleurotus spp. (Bars $=$ Standard deviations) at $30 \pm 2{ }^{\circ} \mathrm{C} .1 \mathrm{~cm}$ rice straw is used as substrate.

initiation of first fruiting flush whereas 1802 desires only $10 \pm 1$ day.

\section{Effect of spawn percentage}

The $\mathrm{BE}$ is better in $20 \%$ spawn than the $10 \%$ spawn in each experiments (Fig. 2) though the spawn \% has no effect on time of fruiting initiation in present experimental condition (data not shown). Maximum increase of $\mathrm{BE}$ is found in 3308. 3308 and 1805 show more or less similar BE at first fruiting flush with 20\% spawn follows by 1799 . $\mathrm{BE}$ is lowest in 6315 . Hence subsequent characterization, morphometric studies and biochemical analysis are done using fruiting bodies obtained from $20 \%$ spawn.

\section{Fruiting life}

The fruiting life (time span from initiation of primordia to deliquescence of fruiting body) varies 4-6 days in 1805, 4-5 days in 1802 and 6315 whereas only 3 days in 1799 and 3308 .

\section{Morphometric studies}

The diameter of pileus and stipe is maximum in 1805 whereas diameter of pileus is lowest in 3308. In 6315, 1802 and 1799 diameter of pileus and stipe slightly varies. Length of stipe is maximum in 1802 and minimum in 1799 (Table-2). Pileus thickness of 1805 is more than other four species. 1802 has moderate thickness whereas 6315 showed least thickness of pileus (Table-2).

The fresh weight of 1805 fruiting body is more than the other strains (Table 3). 1802 shows moderate weight of fruiting bodies. Whereas 6315 and 3308 have less weight of fruiting bodies. The total number of fruiting bodies per bag in present experimental condition is higher in 3308 and lower in 6315 (Table 3).

The measurement of basidium and basidiospores of all the five strains are also taken (Table 4). The length of
Table 1: Effect of substrate length on time ${ }^{a}$ for fruiting initiation ${ }^{b}$ of different strains of Pleurotus spp.

\begin{tabular}{lccc}
$\begin{array}{l}\text { Strain } \\
\text { No. }\end{array}$ & $\begin{array}{c}\text { Substrate } \\
\text { length }\end{array}$ & $\begin{array}{c}\text { Time for initiation } \\
\text { of } \mathbf{1}^{\text {st }} \text { flush }(\mathbf{d})\end{array}$ & $\begin{array}{c}\text { Time for initiation } \\
\text { of } \mathbf{2}^{\text {nd }} \text { flush }(\mathbf{d})\end{array}$ \\
\hline 1802 & $1 \mathrm{~cm}$ & $10 \pm 1$ & $18 \pm 1$ \\
& $5 \mathrm{~cm}$ & $11 \pm 1$ & $19 \pm 1$ \\
1805 & $1 \mathrm{~cm}$ & $13 \pm 1$ & $21 \pm 1$ \\
& $5 \mathrm{~cm}$ & $15 \pm 1$ & $23 \pm 1$ \\
1799 & $1 \mathrm{~cm}$ & $14 \pm 1$ & $\mathrm{Nd}$ \\
& $5 \mathrm{~cm}$ & $14 \pm 1$ & $\mathrm{Nd}$ \\
3308 & $1 \mathrm{~cm}$ & $17 \pm 2$ & $22 \pm 2$ \\
& $5 \mathrm{~cm}$ & $17 \pm 2$ & $22 \pm 2$ \\
6315 & $1 \mathrm{~cm}$ & $24 \pm 2$ & $\mathrm{Nd}$ \\
& $5 \mathrm{~cm}$ & $24 \pm 2$ & $\mathrm{Nd}$ \\
\hline
\end{tabular}

Nd: Not detected. ${ }^{a}$ Mean $\pm S D$, bfruiting bodies were obtained from first flush using $20 \%$ spawn and non-sterilized rice straw $(1 \mathrm{~cm})$ as substrate at $30 \pm 2{ }^{\circ} \mathrm{C}$

Table 2: Morphometric data ${ }^{a}$ of fruiting body ${ }^{b}$ of Pleurotus spp. grown at $30 \pm 2{ }^{\circ} \mathrm{C}$

\begin{tabular}{lcccc}
\hline $\begin{array}{l}\text { Strain } \\
\text { No. }\end{array}$ & $\begin{array}{c}\text { Length of } \\
\text { stipe }(\mathbf{c m})\end{array}$ & $\begin{array}{c}\text { Diameter of } \\
\text { stipe }(\mathbf{c m})\end{array}$ & $\begin{array}{c}\text { Diameter of } \\
\text { pileus }(\mathbf{c m})\end{array}$ & $\begin{array}{c}\text { Thickness of } \\
\text { pileus }(\mathbf{m m})\end{array}$ \\
\hline 1802 & $4.48 \pm 0.32$ & $1.01 \pm 0.19$ & $6.4 \pm 0.20$ & $3.5 \pm 0.5$ \\
1805 & $3.86 \pm 0.18$ & $1.48 \pm 0.32$ & $10.23 \pm 0.37$ & $5.3 \pm 1.8$ \\
1799 & $2.70 \pm 0.20$ & $1.40 \pm 0.50$ & $6.00 \pm 0.32$ & $2.5 \pm 0.3$ \\
3308 & $3.21 \pm 0.21$ & $1.01 \pm 0.40$ & $3.90 \pm 0.90$ & $2.9 \pm 0.5$ \\
6315 & $3.40 \pm 0.20$ & $0.53 \pm 0.18$ & $6.15 \pm 0.19$ & $2.3 \pm 0.7$ \\
\hline
\end{tabular}

${ }^{a}$ Mean \pm SD, bfruiting bodies were obtained from first flush using $20 \%$ spawn and non-sterilized rice straw $(1 \mathrm{~cm})$ as substrate at $30 \pm 2{ }^{\circ} \mathrm{C}$

basidium is maximum in 3308 and minimum in 1799, breadth of basidum is maximum in1805 and minimum in 6315, average area of basidiospore is maximum in 3308 and minimum in 1805. The no. of basidium present per unit area (1000 sq. $\mu \mathrm{m})$ in 6315 is 8 but 4 in 3308 .

Moisture content and dry matter of all the mushroom strains are calculated. Moisture content is maximum in 6315 strain and minimum in 1805 and obviously dry matter is maximam in1805 strain but minimum in 6315 (Table 5). 3308 has highest percentage of ash followed by 1802 whereas the ash percentage of 1805 is less than half of 3308. 1799 and 6315 showed similar amount of ash percentage (Table 5). 1805 contains highest percentage (10.2) of crude fibre followed by 1799. The other strains show very less amount of crude fibre. 3308 shows the least amount of fibre $(1.4 \%)$ content (Table 5).

Measurement of protein, carbohydrate and polyphenols The protein, carbohydrate and polyphenol conc. of all the Pleurotus strains are measured (Table 5). The protein conc. is maximum in 1802 strain moderate in 6315 and 1805 whereas minimum protein conc.is found in 3308 in present experimental condition. The carbohydrate quantity is maxium in 1802 and 6315strains and minimum carbohydrate contents are present in 1805. 1802 and 1805 strains show maximum amount of polyphenols than other species. 1799 shows moderate amount of polyphenols 
Das, et al.: Comparative study of five pleurotus Spp.

Table 3: Measurement ${ }^{a}$ of the weight of individual fruiting body ${ }^{\mathrm{b}}$ of different Pleurotus sp. grown on $30 \pm 2{ }^{\circ} \mathrm{C}$

\begin{tabular}{|c|c|c|c|c|c|}
\hline $\begin{array}{l}\text { Name of } \\
\text { the strains }\end{array}$ & $\begin{array}{c}\text { wt.of } \\
\text { pileus (gm) }\end{array}$ & $\begin{array}{c}\text { wt.of } \\
\text { stipe (gm) }\end{array}$ & $\begin{array}{l}\text { wt.of fruiting } \\
\text { body (gm) }\end{array}$ & $\begin{array}{l}\text { No. of fruiting } \\
\text { body ( } 1^{\text {st }} \text { flush) }\end{array}$ & $\begin{array}{l}\text { No. of fruiting } \\
\text { body (2 } 2^{\text {nd }} \text { flush) }\end{array}$ \\
\hline 1799 & $2.9 \pm 0.20$ & $0.8 \pm 0.11$ & $3.7 \pm 0.15$ & $41 \pm 14$ & $\mathrm{Nd}$ \\
\hline 1802 & $3.6 \pm 0.22$ & $0.9 \pm 0.12$ & $4.5 \pm 0.17$ & $24 \pm 8$ & $12 \pm 3$ \\
\hline 1805 & $5.4 \pm 2.00$ & $1.1 \pm 0.22$ & $6.6 \pm 2.10$ & $23 \pm 9$ & $14 \pm 4$ \\
\hline 3308 & $1.7 \pm 0.10$ & $0.9 \pm 0.11$ & $2.6 \pm 0.10$ & $58 \pm 4$ & $48 \pm 4$ \\
\hline 6315 & $1.8 \pm 0.10$ & $1.1 \pm 0.14$ & $2.9 \pm 0.12$ & $18 \pm 5$ & $\mathrm{Nd}$ \\
\hline
\end{tabular}

Nd: Not detected. ${ }^{a}$ Mean \pm SD, bfruiting bodies were obtained from first flush using $20 \%$ spawn and non-sterilized rice straw $(1 \mathrm{~cm})$ as substrate at $30 \pm 2{ }^{\circ} \mathrm{C}$

Table 4: Morphometric data ${ }^{\mathrm{a}}$ of basidium and basidiospores of different Pleurotus strains ${ }^{\mathrm{b}}$ grown on $30 \pm 2{ }^{\circ} \mathrm{C}$

\begin{tabular}{lcccc}
\hline $\begin{array}{l}\text { Strain } \\
\text { No. }\end{array}$ & $\begin{array}{c}\text { Length of } \\
\text { basidium } \\
(\mu \mathrm{m})\end{array}$ & $\begin{array}{c}\text { Breadth of } \\
\text { basidium } \\
(\mu \mathrm{m})\end{array}$ & $\begin{array}{c}\text { No. of } \\
\text { basidium per } \\
1000 \text { sq. } \boldsymbol{\mu m}\end{array}$ & $\begin{array}{c}\text { Area of } \\
\text { basidiospore } \\
(\text { sq. } \mu \mathrm{m})\end{array}$ \\
\hline 1799 & $16.4 \pm 2.0$ & $4.7 \pm 0.8$ & 6 & $11.37 \pm 2.3$ \\
1802 & $20.3 \pm 2.5$ & $3.33 \pm 0.8$ & 5 & $7.65 \pm 1.2$ \\
1805 & $22.3 \pm 2.2$ & $6.24 \pm 1.1$ & 6 & $6.20 \pm 1.2$ \\
6315 & $26.5 \pm 3.8$ & $2.90 \pm 0.4$ & 8 & $8.95 \pm 1.6$ \\
3308 & $29.2 \pm 3.4$ & $4.10 \pm 1.0$ & 4 & $15.68 \pm 2.2$ \\
\hline
\end{tabular}

${ }^{\mathrm{a}}$ Mean \pm SD, bfruiting bodies were obtained from first flush using $20 \%$ spawn and non-sterilized rice straw $(1 \mathrm{~cm})$ as substrate at $30 \pm 2{ }^{\circ} \mathrm{C}$

whereas 6315 and 3308 show least amount of polyphenols (Table 5).

\section{Measurement of sodium and potassium content}

$\mathrm{Na}$ and $\mathrm{K}$ contents in different Pleurotus strains are measured from the dried mushroom powder (Table 6). Potassium content of all the oyster mushroom strains are superior than their sodium content. The potassium content varies from 18.00 to $23.43 \mathrm{ppm}$ whereas sodium content varies from 5.81 to $10.56 \mathrm{ppm}$.

\section{DISCUSSION}

In comparison to button mushroom cultivation of oyster mushroom (Pleurotus spp.) is very much simple and the agroclimatic condition of India is very much encouraging for their farming. Though Pleurotus cultivation has been accomplished very efficiently within the temperature range of $22-27{ }^{\circ} \mathrm{C}$ (Ashraf et al, 2013) but the present investigation has been carried out in slightly higher temperature range i.e. $(30 \pm 2){ }^{\circ} \mathrm{C}$. Oyster mushroom can be cultivated on a large no of lignocellulosic substrates like wood log, straw, vegetable peels even on weeds (Gregori et al, 2007). Pavlik (2005) reported that the biological efficiency of P. ostreatus varies from substrate to substrate. Different types of straw are by and large used for commercial production of Pleurotus. Though for commercial purposes pasteurized or composted straw are used but nonpasteurized straw are also used for cultivation of oyster mushroom (Das et al, 2007, 2010).

In the present investigation two types of rice straw are used. One of very small length about $1.0 \mathrm{~cm}$ another of $5.0 \mathrm{~cm}$ length. The results show that the biological efficiencies are much better in the straw with lower length than the straw with higher length (Fig. 1). For primordia initiation, the time requirement are same or slightly less in smaller length of substrates. (Table-1). Possibly the fungi availed more surface area for colonization in tiny substrates. Zhang et al. (2002) reported similar result where ground straw showed better efficiency than chopped straw. The BE is better in 20\% spawn than the 10\% spawn (Fig. 2). Zhang et al (2002) reported higher spawn percentage enhanced mushroom yield. Here the spawn \% has no effect on time of fruiting initiation. BE is more or less comparable in P. florida (3308) and P. pulmonarius (1805) followed by P. flabellatus (1799) and P. ostreatus (1802). BE is lowest in P. floridanus. 3308 showed about $73 \%$ increase in BE of first flush by increasing the spawn percentage from 10 to 20 (Fig. 2). Asraf et al (2013) showed highest yield in P. ostreatus than P. sajorcaju and P. dimor. However, Obodai et al (2000) have been found lower biological efficiency in P. ostreatus. The time for primordia initiation is more in P. floridanus and less in P. ostreatus (Table 1). Many workers showed that initition of fruiting body is dependent on type and quality of substrates (Gregori et al, 2007).

The length of stipe, diameter of pileus etc are some unique characters of mushroom which varies from species to species. Here the legth of stipe is maximum in P. ostreatus (1802) (Table 2).

The fresh weight of individual fruiting body is more in P. pulmonarius than other tested strains (Table 3). $P$. ostreatus shows moderate weight of fruiting bodies. Whereas P. floridanus and P. florida have less weight of fruiting bodies. Neelam and Singh (2013) showed that the fresh wt. of P. florida as $1.34-1.55 \mathrm{~g}$ and P. ostreatus as $1.32-1.47 \mathrm{~g}$. The total number of fruiting bodies per bag in present experimental condition is lower in P. floridanus and higher in P. florida (Table 3).

As the genus Pleurotus belongs to subdivision basidiomycotina so characters of basidium and basidiospores are important. Table 4 shows some of these characters which might be important for taxonomical studies.

Moisture content and dry matter of any living matter is reciprocal to each other. Moisture content is maximum 
Das, et al.: Comparative study of five pleurotus Spp.

Table 5: Determination ${ }^{\mathrm{a}}$ of various physiochemical parameters of different Pleurotus spp. ${ }^{\mathrm{b}}$ grown on $30 \pm 2{ }^{\circ} \mathrm{C}$

\begin{tabular}{|c|c|c|c|c|c|c|c|}
\hline $\begin{array}{l}\text { Strain } \\
\text { No. }\end{array}$ & $\begin{array}{c}\text { Moisture } \\
(\%)\end{array}$ & $\begin{array}{c}\text { Dry } \\
\text { matter (\%) }\end{array}$ & $\begin{array}{c}\text { Crude } \\
\text { fibre (\%) }\end{array}$ & Ash (\%) & $\begin{array}{c}\text { Protein } \\
(\mu \mathrm{g} / \mathrm{g} \text { tissue })\end{array}$ & $\begin{array}{c}\text { Carbohy-drate } \\
(\mu \mathrm{g} / \mathrm{g} \text { tissue) }\end{array}$ & $\begin{array}{l}\text { Polyphenol } \\
\text { ( } \mu \mathrm{g} / \mathrm{g} \text { tissue) }\end{array}$ \\
\hline 1799 & $87.5 \pm 0.21$ & $12.5 \pm 0.21$ & $6.6 \pm 0.19$ & $5.9 \pm 0.09$ & $392 \pm 13$ & $216 \pm 12$ & $53.75 \pm 7.8$ \\
\hline 1802 & $88.2 \pm 0.15$ & $11.8 \pm 0.15$ & $3.1 \pm 0.06$ & $8.7 \pm 0.19$ & $856 \pm 29$ & $260 \pm 18$ & $67.85 \pm 9.7$ \\
\hline 1805 & $85.0 \pm 0.18$ & $15.0 \pm 0.18$ & $10.2 \pm 0.25$ & $4.8 \pm 0.06$ & $417 \pm 17$ & $208 \pm 14$ & $65.40 \pm 9.4$ \\
\hline 3308 & $88.0 \pm 0.16$ & $12.0 \pm 0.16$ & $1.4 \pm 0.08$ & $10.6 \pm 0.16$ & $294 \pm 21$ & $228 \pm 17$ & $18.90 \pm 3.3$ \\
\hline 6315 & $91.1 \pm 0.19$ & $8.9 \pm 0.19$ & $2.8 \pm 0.09$ & $6.1 \pm 0.12$ & $448 \pm 23$ & $255 \pm 21$ & $16.40 \pm 2.9$ \\
\hline
\end{tabular}

${ }^{\mathrm{a}} \mathrm{Mean} \pm \mathrm{SD}$, bfruiting bodies were obtained from first flush using $20 \%$ spawn and non-sterilized rice straw $(1 \mathrm{~cm})$ as substrate at $30 \pm 2{ }^{\circ} \mathrm{C}$

Table 6: Quantification ${ }^{a}$ of $\mathrm{Na}$ and K in different Pleurotus strains ${ }^{\mathrm{b}}$

\begin{tabular}{lcc}
$\begin{array}{l}\text { Strain } \\
\text { No. }\end{array}$ & $\begin{array}{c}\text { Average quantity of } \\
\text { Potassium }(\mathbf{p p m})\end{array}$ & $\begin{array}{c}\text { Average quantity } \\
\text { of Sodium }(\mathrm{ppm})\end{array}$ \\
\hline 1799 & $22.17 \pm 3.1$ & $10.56 \pm 1.7$ \\
1802 & $22.41 \pm 1.8$ & $6.28 \pm 0.9$ \\
1805 & $23.43 \pm 2.1$ & $20.86 \pm 1.9$ \\
3308 & $23.41 \pm 2.4$ & $5.81 \pm 1.6$ \\
6315 & $18.00 \pm 1.9$ & $10.10 \pm 2.1$ \\
\hline
\end{tabular}

${ }^{a}$ Mean \pm SD, bfruiting bodies were obtained from first flush using $20 \%$ spawn and non-sterilized rice straw $(1 \mathrm{~cm})$ as substrate at $30 \pm 2{ }^{\circ} \mathrm{C}$

in P. floridanus and minimum in P. pulmonarius (Table 5). Menaga et al (2012) showed the moisture content of P. florida was about $87.3 \%$ whereas Ahmed et al (2009) showed 92.3\%. Ashraf et al (2013) showed 87.3\% moisture content in $P$. sajorcaju. In the present investigation moisture content varies from $85 \%$ (P. pulmonarius) to $91 \%$ in P. floridanus (Table 5). P. florida has highest percentage of ash followed by $P$. ostreatus whereas the ash percentage of P. pulmonarius has less than half of P. florida (Table 5). P. flabellatus and P. floridanus show moderate amount of ash percentage. $P$. pulmonarius contains highest percentage (10.2) of crude fibre followed by P. flabellatus (6.6). The other strains show very less amount of crude fibre. $P$. florida shows only $1.4 \%$ fibre (Table 5 ).

As Pleurotus is one of the most important edible mushroom so the biochemical characterization is very much needed to conclude its nutritional values (Table 5). In the present study the protein concentration is highest in P. ostreatus, moderate in $P$ floridanus and $P$. pulmonarius whereas minimum protein concentration is found in P. florida. The amount of carbohydrate is maximum in $P$. ostreatus and $P$. floridanus strains and minimum carbohydrate is present in P. pulmonarius (Table 5). Dundar et al. (2008) showed that the carbohydrate content of P. ostreatus, P. sajorcaju and P. eryngii as $37.87,37.72$ and $39.85 \mathrm{~g} / 100 \mathrm{~g}$ dry material, respectively. $P$. ostreatus and $P$. pulmonarius strains show maximum quantity of polyphenols than other species. P. flabellatus shows moderate amount of polyphenols whereas $P$. floridanus and P. florida show least amount of polyphenols (Table 5).

The presence of high potassium content over sodium in diet suggests the effectiveness against hypertension (Manzi et al., 2004). Here all the Pleurotus sp. contains high potassium to sodium ratio, which makes them ideal food for patients suffering from hypertension and heart diseases. Potassium sodium ratio in present experimental set up is maximum in P. florida (3308) and minimum in $P$. pulmonarius.((Table 6).

\section{CONCLUSION}

Temperature plays a critical role in fruiting body development in different mushroom including Pleurotus spp. In the present investigation the BE, morphometrics of fruiting body and basidium and chemical characterization of fruiting bodies of five different Pleurotus spp. were done using rice straw as substrates at $(30 \pm 2){ }^{\circ} \mathrm{C}$. The $\mathrm{BE}$ not only varies from species to species but also on quality of substrates (length) and spawn percentage. Protein, carbohydrate, polyphenol, sodium potassium contents of different strains of Pleurotus spp are also studied and compared with other available literatures. This is possibly the first report of cultivation of such a number Pleurotus spp. in warm temperature $30 \pm 2{ }^{\circ} \mathrm{C}$ using non sterilized rice straw as the substrate.

\section{ACKNOWLEDGEMENTS}

ND acknowledges the financial help from UGC, India. Project No. F.PSW-144/13-14 (ERO) dated 18.03.2014. We also acknowledge the help of Dr. Saikat Naskar of our department particularly for statistical analysis.

\section{Authors' contributions}

ND and NCK developed the concept and designed the experiments. SM and LB done the experiments. ND wrote the manuscript and overall supervised the work.

\section{REFERENCES}

Ahmed, S. A., J. A. Kadam, V. P. Mane, S. S. Patil and M. M. Baig. 2009. Biological efficiency and nutritonal contents of Pleurotus florida (Mont) singer cultivated on different agroresidues. Nat. Sci. 7: 44-48.

Ashraf, J., M. A. Ali, W. Ahmad, C. M. Ayyub and J. Shafi. 2013. Effect of different substrate supplements on Oyster mushroom (Pleurotus sp.) production. Food Sci. Technol. 1: 44-51. 
Biswas, S., M. Datta and S. V. Ngachan. 2012. Mushrooms: A Manual for Cultivation, PHI Learning Pvt. Ltd., New Delhi, India.

Chang, S. T. 1999. World production of cultivated and medicinal mushrooms in 1997 with emphasis on Lentinus edodes (Berk) Sing, China. Int. J. Med. Mushroom. 1: 291-300.

Croan, S. C. 2004. Conversion of conifer wastes into edible and medical mushroom. For. Prod. J. 54: 68-76.

Das, N. and M. Mukherjee. 2007. Cultivation of Pleurotus ostreatus on weed plants. Bioresour. Technol. 98: 2723-2726.

Das, N., P. Chowdhury and B. Pasman. 2010. Cultivation practice of Pleurotus fossulatus on rice straw. J. Life Sci. 4: 20-25.

Dundar, A., H. Acay and A. Yildiz. 2008. Yield performances and nutritional contents of three oyster mushroom species cultivated on wheat stalk. Afr. J. Biotech. 7: 3497-3501.

Gregori, A., M. Svagel and J. Pohleven. 2007. Cultivation techniques and medicinal properties of Pleurotus spp. Food Technol. Biotechnol. 45: 238-249.

Khan, N. A., M. Ajmal, J. Nicklin, S. Aslam and M. A. Ali. 2013. Nutritional value of Pleurotus (flabellatus) djmor (r22) cultivated on sawdust of different woods. Pak. J. Bot. 45: 1105-1108.

Kurtzman, P. H. Jr. 1976. Nutrition of Pleurotus sapidus effects of lipids. Mycologia. 68: 268-295.

Lowry, O. H., N. J. Rosebrough, A. L. Farr and R. J. Randall. 1951. Protein measurement with the Folin phenol reagent. J. Biol. Chem. 193: 265-275.

Mane, V., P. Patil, S. S. Syed and M. M. Baig. 2007. Bioconversion of low quality lignocellulosic agricultural waste into edible protein by Pleurotus sajor-caju (Fr.) Singer. J. Zhejiang Univ. Sci. 8: 45-50.
Manzi, P., S. Marconi, A. Aguzzi and L. Pizzoferrato. 2004. Commercial mushrooms: Nutritional quality and effect of coocking. Food Chem. 84: 201-206.

Neelam, S. and S. Singh. 2013. Comparative in vitro studies on phytochemical and antibacterial properties of ethanol extracts of Pleurotus florida and Pleurotus ostreatus. Int. J. Pharm. Bio. Sci. 4: 396-400.

Novaes, M. R., L. C. Novaes and V. C. Taveira. 2007. Pharmacological effects of agaricales fungi: A review of evidence. Rev. Cinc. Med. Camp. 16: 87-95.

Obodai, M., J. Cleland-Okine and K. A. Vowotor. 2003. Comparative study of the growth and yield of Pleurotus ostreatus on different lignocellulosic by products. J. Ind. Microbiol. Biotechnol. 30: 146-149.

Pavlik, M. 2005. Growing of Pleurotus ostreatus on woods of various deciduous trees. Acta Edulis Fungi. 12: 306-312.

Pons, A., P. Roca, C. Aguiló, F. J, Garcia, M. Alemany and A. Palou. 1981. A method for the simultaneous determination of total carbohydrate and glycerol in biological samples with the anthrone reagent. J. Biochem. Biophys. Methods. 4: 227-231.

Purkayastha, R. P. and D. Nayak. 1981. Development of cultivation method and analysis of protein of promising edible mushroom Calocybe indica P and C. Mushroom Sci. 11: 697-713.

Sanchez, C. 2010. Cultivation of Pleurotus ostreatus and other edible mushrooms. Appl. Microbiol. Biotechnol. 85: 1321-1337.

Weinheim, K. G. 2006. Oyster Mushroom, John Wiley and Sons Inc., New York, USA.

Zhang, R., X. Li and X. J. Fadel. 2002. Oyster mushroom cultivation with rice and wheat straw. Bioresour. Technol. 88: 277-284. 